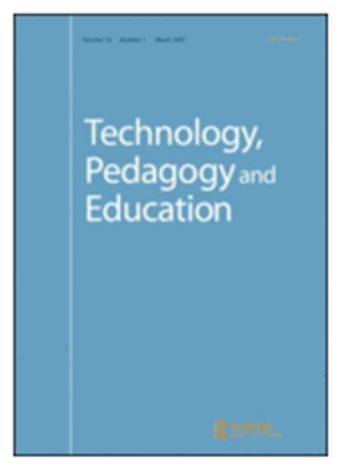

High Possibility Classrooms as a pedagogical framework for technology integration in classrooms: An inquiry in two Australian secondary schools

\begin{tabular}{|r|l|}
\hline Journal: & Technology, Pedagogy and Education \\
\hline Manuscript ID & RTPE-2016-0033.R1 \\
\hline Manuscript Type: & Original Article \\
\hline Keywords: & technology integration, pedagogy, secondary school education, theory \\
\hline \multicolumn{2}{|}{} \\
\hline
\end{tabular}




\title{
High Possibility Classrooms as a pedagogical framework for technology integration in classrooms: An inquiry in two Australian secondary schools
}

\author{
Understanding how well teachers integrate digital technology in learning is the \\ subject of considerable debate in education. High Possibility Classrooms (HPC) \\ is a pedagogical framework drawn from research on exemplary teachers' \\ knowledge of technology integration in Australian school classrooms. The \\ framework is being used to support teachers who teach various stages of \\ schooling to take 'pedagogical steps' in their practice with technology. This \\ paper focuses on the use of the HPC conceptual framework in a study of seven \\ teachers and their students at two secondary schools in New South Wales \\ (NSW), Australia. Analysis confirms the practicality of this conceptual \\ framework for technology integration in secondary school classrooms. This \\ inquiry has implications for addressing the reluctance of teachers to integrate \\ technology in curriculum, and the paper concludes by suggesting that more \\ schools might consider using conceptual frameworks like HPC to support \\ secondary school teachers to enhance student learning with technology.
}

Keywords: technology integration; pedagogy; secondary school education; conceptual frameworks, theory 


\section{Introduction}

There is no doubt that pedagogical change in many secondary schools is urgent (Robinson \& Aronica, 2015; Wagner \& Dintersmith, 2015). In a keynote address at a education technology conference in Sydney, Australia, Professor Eric Mazur (2016) from Harvard University claimed: "students are more asleep during lectures than when they are in bed". This statement penetrates to the core of what some secondary school students experience every day in classrooms: pedagogy reliant on didactic approaches, memorisation and test-based assessments. These are common practices in Australian secondary schools (Evers \& Kneyber, 2016; Lingard, Thompson, \& Sellar, 2016).

This paper reports on research conducted with six classroom teachers in two New South Wales (NSW) secondary schools and a head teacher from one of these schools. The classroom teachers identified that their use of a pedagogical framework known as High Possibility Classrooms (HPC) for technology enhanced learning supported them to plan and program engaging lessons for young people in their classrooms. Students in these teachers' classrooms described 'a different approach' and expressed liking their learning more when the classroom was less teacher centred; indeed, they pleaded for teachers in other classes to 'stop lecturing them'.

To foreground this discussion, it is important to understand that the HPC framework, the subject of this paper, is not simply a set of instructional strategies. It is a conceptual framework (Miles \& Huberman, 1994) that emerged from research (Author, 2013) on exemplary teachers' knowledge of technology integration in the classrooms of Australian school students aged 6 to 16 years (Belbase, 2016; Groundwater-Smith \& Mockler, 2016; Reynolds, 2015). Teachers in the original study conceptualised their knowledge of digital technology integration based on theory, creativity, public learning, 
life preparation and contextual accommodations; these five conceptions are supported by 22 underpinning themes of pedagogical strategies and student learning processes (Author, 2013, 2015a, 2015b).

The HPC framework's validity was further strengthened in a later study (Author, 2015a), and it is now being used by an increasing number of teachers in primary and secondary schools in Australia as a means to shift pedagogical practices and better align students' digital lives outside school with classroom learning that is premised on inquiry, solving real world problems and critical thinking (Hewes, 2016; Lin, Zhang, \& Zhang, 2017; Littlejohn, 2016). HPC is the subject of a number of ongoing studies. The concern of the research reported in this paper is whether a pedagogical framework developed from exemplary teachers' knowledge of technology integration could be enacted to support and change pedagogy to more student-centred approaches in the classrooms of the teachers who participated in the study, without it having to fit purposive criteria like those in the earlier study (Author, 2013).

The terms technology and technology integration used here refer to tools created by human knowledge to combine resources to produce desired products, solve problems, fulfil needs or satisfy wants. As such, they include digital technology and how it is used or integrated for learning in schools (Author, 2015a).

\section{Background literature}

\section{Frameworks for technology integration in schools}

Pedagogical frameworks for technology integration play a critical role in supporting teachers in schools to take risks with approaches to teaching that afford students opportunities to learn in different ways (Groff \& Mouza, 2008). Conceptual frameworks like TPACK (Technological Pedagogical Content Knowledge) developed by Mishra 
and Koehler (2006) have taken the scholarship of technology integration ahead in this area. Thousands of studies of TPACK have led teachers, schools leaders, education systems and policy makers to explore and re-think ways to enact technology integration in education settings (Graham, 2011; Harris \& Hofer, 2014; Koh, Chai, \& Lee, 2015). For many experienced teachers, the development of TPACK reminds them:

Selecting adapting, and designing learning acivities, projects, and units is review work but the awareness of how digital tools and nondigital tools can be used in the service of students' learning ... encompasses new information ... about the planning/instructional design process. (Harris, 2008, p. 266)

HPC is a fresh conceptual framework for technology integration that has taken the TPACK framework and built on it from research on exemplary teachers' knowledge of technology integration in Australian primary and secondary school classrooms (Hewes, 2016; Littlejohn, 2016). The framework's five conceptions of theory, creativity, public learning, life preparation and contextual accommodations (see Figure 1) form an evidence-based scaffold that reflects these teachers' knowledge of technology integration in action. Each conception is underpinned by themes of pedagogical strategies and students' learning processes (see Table 1). For example, the first conception, theory, refers to how:

[The] teacher's technology philosophy in the classroom affects practice, and is supported by themes: the construction of learning, purposeful teaching, and planning ... [and] through implementation of these themes, the teacher's actions impact students learning processes of enriching subject matter ... reflective learning and shifting conversations and thinking ... it engages students in authentic ways. (Author, 2015a, p. 150) 
The other four HPC conceptions are also potent forces in the teachers' knowledge of technology integration. The second conception, creativity, has five themes: boosting learning through technology, creating opportunities for production, unleashing playful moments, supporting the teachers values and enabling differentiation of learning. In the public learning conception, technology scaffolds the performance of students' work in front of peers or for online audiences, and it enhances their learning outcomes. The fourth conception, life preparation, is supported by technology that operationalises the real world for students, gives them a voice, denotes ownership and responsibility, and is effective in engaging and motivating them. Contextual accomodations is the fifth conception. This refers to the understanding that while exemplary teachers' knowledge is considered personal they also have a professional responsibility for scheduling longer blocks of learning time over the school day, nurturing the community of learners in their classrooms, and using technology to 'define the game' of effective teaching (Author, 2015a; Belbase, 2016; Groundwater-Smith \& Mockler, 2016).

$<$ Insert Figure 1 approximately here $>$

$<$ Insert Table 1 approximately here $>$

Some realities of technology in Australian secondary school classrooms and elsewhere

The Digital Education Revolution (DER) between 2008 and 2011 was the largest technology policy ever initiated by the Australian Government (Moyle, 2015). The AUD 2 billion program placed a mobile device in the hands of every public secondary school student in Years 9 to 12. Reports of its policy effects (Masters, 2014) and pedagogical impacts are inconclusive (Arthur, 2013; Howard \& Mozejko, 2013). However, what the DER did achieve was the provision of equitable access to a 
technological tool that had 'significant catalytic impact on secondary schools and secondary school teaching across Australia' (Danolo Partners, 2013, p. 5). It disrupted the status quo and challenged the existing, mostly teacher-centred, pedagogies in senior secondary school classrooms (Howard \& Gigliotti, 2013).

We are reminded in other education literature that the promise of more democratic, fairer roles for digital technologies has not been realised. Expressing unease, Selwyn (2014) writes 'the gulf ... persists between the rhetoric of how digital technologies could be used in education and the realities of how digital technologies are actually used in education' (p. vii). There is an urgent need address the untidy reality of technology use in secondary school classrooms, where it has a necessary place in school learning.

Wagner \& Dintersmith (2015) argue that for young people to live well now and in the future there needs to be a re-imagining of school education. The examining of teachers' pedagogical approaches to technology integration is a core component of their call for improved schooling experiences for young people. At the White House Summit on Next Generation High Schools (The White House, 2015) there was widespread agreement that the current model of secondary education does not serve students well in terms of engagement, authenticity, and preparation for college or their future careers.

This urgent call is also seen in education reports from the United Kingdom (Department for Education, 2010; Evers \& Kneyber, 2016; Kelly, 2012), and resonates with an important account (Fullan \& Langworthy, 2014) that calls for a 'radical change in relationships between all of the key players in learning: students, teachers, technologies, school cultures, curricula and assessments' (p. 2). New and emerging pedagogies require students to create fresh knowledge and connect it to the world using the power of technology. The role of project-based learning (PBL) is common in such visions of 
secondary school education where technology integration is important, and it provides opportunities for students to engage in inquiry and leverage solutions to problems that are vital to them and to the world outside (Boss \& Krauss, 2014). Education research needs to assist teachers in secondary schools to more effectively integrate technology in student learning and understand how they may enact practice using new pedagogical frameworks.

The main research question of this study was:

How does the HPC framework support secondary school teachers to integrate technology into student learning?

Two sub-questions underpinned the main question:

i) What HPC conceptions and themes do the teachers use in lessons?

ii) How do teachers use a pedagogical framework like HPC to make learning more engaging for students?

\section{Research context}

The schools in the study, Melton High School (MHS) and Bally High School (BHS), are public schools located in the northern suburbs of a major city and cater for students aged 13 to 18 years. MHS is a medium-sized, academically selective co-educational school, and BHS is a large comprehensive boys' school. At both schools WiFi connectivity is inconsistent on most days, students have the option of bringing their own technology devices, and the learning spaces are traditional, meaning they are often small with rows of desks and chairs. The two sites were chosen on the basis that being involved in a research project fitted with their 'other school commitments' and there was a group of teachers in each who desired to integrate more technology into their classroom practices. 
The six classroom teachers who contributed represented a mix of curriculum areas and taught a blend of student age groups $(\mathrm{N}=143)$. They had varying lengths of teaching experience, ranging from early career to more than 30 years. The schools and participants are given pseudonyms. Table 2 gives further demographic details of the participating teachers.

$<$ Insert Table 2 approximately here $>$

Groups of six to eight students selected at random from the teachers' classrooms representing a diversity of backgrounds participated in four focus groups $(\mathrm{N}=34)$. All teachers and students were informed of the research directions and ethical protocols.

\section{Methodology : research design and analysis}

The qualitative approach used for the research is consistent with case study methodology (Yin, 2009) involving classroom observations, teacher interviews, student focus groups and document analysis. Subjectivity in case study research is always a limitation (Abma \& Widdershoven, 2011), and it was with these constraints in mind that the research proceeded. Participating teachers were recruited from an invitation sent to all secondary public school principals in NSW. Member checks were carried out on transcripts created from interviews and focus groups; collected data was managed using NVivo 11 qualitative software and stored securely. The state education regulator endorsed the workshop as accredited teacher professional development (PD), and the study was approved by the University Human Ethics Research Committee (No. H100381) and was also agreed to by the State Education Research Approvals Process (No. 2013-2015232). 


\section{Design of the study}

All teacher participants attended a two-hour HPC familiarisation workshop conducted by the researcher. The workshop agenda included:

- an explanation of the original HPC research (Author, 2013) and how exemplary teachers' conceptualised their knowledge of technology integration

- viewing video examples of student work

- distribution of a resource handbook that summarised key theoretical technology integration models, including TPACK (Mishra \& Koehler, 2006).

After the workshop participating teachers spent time with the head teacher of MHS, planning and programming a minimum of two lessons using the HPC conceptions and themes. Each teacher was observed and interviewed twice. Questions covered the workshop, how they used HPC, whether it was supportive or not and examples of engaging lessons. Classroom observations were recorded on a digital grid setting out the presence or absence of the HPC conceptions and themes. Student focus groups took place after the lesson observations and discussed questions about technology and what it meant in the classroom. Questuions required students to give examples of what they liked about technology, what was not helpful, their favourite technology lesson/s and subjects, and whether or not they learned better/or were more engaged when they used technology in the curriculum area they were studying.

Analysis

Codes were generated from the first sets of teacher data; names assigned to the codes were created from the original study (Author, 2013) and included the five HPC conceptions shown in Figure 1. Numbers of codes were reduced at this point, prior to 
importing them into the qualitative software to code the remaining five data sets when open coding commenced in earnest. Seven case summaries involving careful cross-case processes were prepared from the analysis and presented and adjusted after a conversation with each participant (Author, 2017; Miles \& Huberman, 1994). The case summaries form the data reported in the results.

\section{Results}

Research findings are presented as seven vignettes that form one case study. The first six are teacher vignettes enriched with comments from the student focus groups, and the seventh features reflections from the head teacher at MHS, Bella, who was instrumental in the inquiry. Vignettes 1 to 3 relate to teachers from MHS, and 4 to 6 to teachers from BHS. For ease of reading, the dominant HPC conceptions (noted in bold text) and themes (noted in italics) are distinguished in each teacher vignette. A summary draws attention back to the findings as a response to the research questions.

\section{Vignette 1: Jacob}

Jacob was new to MHS having just arrived from his first teaching position at a secondary school in a rural setting. In a computer lab, Jacob's Health and Physical Education (HPE) students engaged in constructing a blog to promote healthy lifestyles: 'Blogs really help me to focus my planning' (Jacob, Interview 1). Understanding content from the syllabus and making it public on a blog was a motivating factor. Field memos recorded in classroom observations confirmed the students' focus and engagement on the task.

When Jacob checked the blog after each class he commented on the extended responses from quiet students: 'Students don't always feel comfortable in class. When 
they use technology they can jump online and comment on what other students are saying - those silent students have some great ideas' (Jacob, Interview 2). He used his rural connections to link the blog created in a city-based context to a blog generated by a teacher and same-age students in a HPE class at his previous school:

The students here don't understand the demographic out there at [rural town] it is a chance for them to connect with rural students and build a community through blogging and sharing what they know beyond the classroom - it pushes them to produce work of a higher standard. (Jacob, Interview 1)

Jacob viewed blogs as creative tools, they assisted him with differentiating learning for students and were an opportunity to 'push him out of his professional comfort zone'. He said, 'I am not a blogger but when you try new tech in what you are planning to teach it forces you to experiment' (Jacob, Interview 1).

In the focus group, Jacob's students reinforced their passion for using technology in HPE: 'I liked that first lesson on blogs, it is an interesting way to learn about healthy things ... we can talk to people we wouldn't normally meet and express our opinions' (Focus group, Year 7, MHS). They also expressed a fondness for technology they had used in primary school and spoke at length about why it was an important skill to have for the future. There was also deep frustration with not sustaining their familiarity with technology: 'I have found they haven't introduced us to a lot of new tech ... we just keep revising all the same things on computers.' Students spoke about the nature of some teachers' technology abilities; one student spoke in blunt terms: 'I think teachers in secondary schools as well as providing technology for students - the teachers need to have an education in technology.' 
In summary, Jacob used the HPC conception of theory to construct the learning, to plan, to reflect and make his students' learning more authentic. The second conception of creativity was realised through the manner in which he gave students opportunities to produce; in this case they developed a blog. They 'played online' with the connections they made to rural students, the lessons allowed differentiation, and there was strong support for the value of technology and why it makes learning engaging for young people. Public learning was evident when students presented their work and responded to blog posts from peers, and their HPE reports towards the end of term noted a clear upward trend. In life preparation, the real world task of creating an online response to a healthy lifestyle task was significant in promoting ownership and responsibility. In contextual accommodations Jacob spoke about how technology nurtured community in the classroom.

\section{Vignette 2: Carrie}

Carrie came to her education career from a previous position as a professional marine scientist. She had worked in special schools and questioned the role of technology in education and whether or not teachers 'really know the best way' to use it. In Science lessons examining the cardiovascular, respiratory and kidney systems in the human body she focused on creativity. Students worked in small teams in the school library to create artefacts to communicate their understandings. Carrie expressed a lack of confidence and preferred to co-teach the lessons with support from the head teacher, Bella, and the teacher-librarian.

After both lesson observations, Carrie expressed reticence in terms of whether technology gave students opportunities to be creative: 'I can also be creative without it. There is nothing limiting me in a lesson on surface tension. For example, I can get a 
paper clip to float - I am only limited by what I choose to do' (Carrie, Interview 1). She believed that technology enhanced skill development in young people; nonetheless, she was more concerned about them not being on task.

Students in Carrie's class liked using technology for taking notes and sharing information. They also expressed apprehension about 'too much screen time' and whether 'sticking to handwriting should be encouraged by the school' (Focus group, Year 8, MHS). Prompted further, they shared fond memories of projects completed in Year 7, one in particular where they built a planet: 'It was a mix of technology and nontechnology ... you could gather information on a range of topics and we got to present it to a group of Year 10 students.' All students chimed in about how much they enjoyed doing projects involving the use of technology to learn curriculum content.

In summary, although Carrie stated that creativity was to be her main HPC focus, the classroom observations, document analysis and interviews proved otherwise. She used theory through planning and construction of an authentic task to enrich the subject matter of learning about the human body. As well, her students had to present their work to the whole class (public learning), and by conducting research in teams, which included preparing, recording and editing, they demonstrated the HPC conception of life preparation. In addition, the evidence for contextual accommodations showed that longer blocks of learning time were given to the task as students became engaged, and their working in collaborative ways nurtured the community of learners.

\section{Vignette 3: Katrina}

Katrina liked using technology but found it often replaced pedagogy that could just as easily involve traditional approaches; she valued expert teachers who made specific 
suggestions about effective applications and web-based resources for the English units she taught. The theory conception was used to target construction of learning, focus planning and promote reflective learning. Katrina also used another pedagogical framework, Quality Teaching (NSW Department of Education, 2003), which has a dimension of 'significance' that is reflected in the HPC framework. She said, 'The HPC framework resonated with Quality Teaching, because I try to be really conscious of that in my teaching and when I am planning lessons - I reflect on my lessons as much as possible' (Katrina, Interview 1).

The creativity conception was obvious in expectations that opportunities to boost creativity would culminate in students making a product, in this case a satirical meme. One student confirmed Katrina's intention: 'Satire is always fun, we are doing a film ... you learn more when you can create things using technology (Focus group, Year 10, MHS). In public learning, Katrina made specific digital resources available online that would support students to complete the meme. She saw this as an essential step in developing PBL skills: the outcome of what students produce must always have a real audience. She said, 'Online technology helps you to follow students learning publicly' (Katrina, Interview 2). She also acknowledged that she aspired to get much better at integrating technology. Students concurred, wanting their learning 'out there [but it] really depended on the teacher and in English it was interesting content so we are less likely to use the alt-tab and be off-task playing games' (Focus group, Year 10, MHS).

Life preparation in Katrina's classroom focused on operationalising the real world and ownership and responsibility: 'PBL on satire using technology is about producing young people to be good citizens and the power of their vote - choosing a 
contentious issue and satirising it ... they collaborate and critically think' (Katrina, Interview 2).

Contextual accommodations was apparent when classroom design restricted pedagogical approaches involving technology:

I think there are bureaucratic problems that prevent successful technology integration ... you cannot get into the computer rooms and students don't all bring devices - the iPads we were given to use never connected wirelessly ... sometimes the 'how in tech' is not thought through - it's a shame. (Katrina, Interview 1)

On this topic, one of Katrina's students was vocal: 'I don’t use my laptop because it's hard to connect to the Internet, also it's distracting and over time our handwriting is being downgraded - some teachers prefer us not to use technology ... I kind of like traditional teaching' (Focus group, Year 10, MHS). Another student added, 'We have to get ready to do three-hour exams in two years time and many of us type slowly.' In summary, Katrina's lessons reflected the planning and programming she did with Bella's assistance, and the data analysis shows the presence of each HPC conception and most of the underpinning themes.

In the following three vignettes of Sue, Noel and Paul at BHS, the focus of observations of their lessons was the weeklong project: My Space - How do we design more effective learning spaces for boys? Conducted in the school library, the project was for gifted and talented students (GATS) who worked in groups, wrote individual blog posts and used digital tools to record their thinking and to present content. The teachers produced a comprehensive booklet to scaffold the students' learning steps. As 
it was a co-taught series of lessons, one summary of the dominant HPC conceptions and themes is provided at the end of Vignette 6.

\section{Vignette 4: Sue}

Sue sought opportunities to use digital media like film and video for her students' learning, often encouraging them to photograph their own work and display it on social media. The PBL task was an occasion for students to reflect on their learning, and the daily blog posts were a means to do this. She said,

I still think it is the teacher's role to set up tech learning opportunities for them and when students record their conversations or thoughts it acts as evidence they can look back over it. (Sue, Interview 1)

Sue liked the way PBL gave students who don't normally work together the opportunity to do so: 'Authentic learning ... a real task like this one gives the boys a chance to make the school look better ... to have their voice heard' (Sue, Interview 1). In the focus group, students spoke about their enjoyment of PBL and their perceived skills in technology, namely touch typing and being able to take effective notes. One boy said, 'It is so much faster ... I am good at typing - so glad we get the chance to use our laptops in projects' (Focus group, Year 7, BHS).

\section{Vignette 5: Noel}

Noel had deep beliefs and capability when using technology with students. He regarded himself as an early adopter: 'Technology enables students and teachers to participate at a much deeper level' (Noel, Interview 1). He approved of the way the GATS program relied heavily on the use of technology to engage students and the fact that students 
could present a real design to a public audience in the project's finale. He pointed out that in terms of seamless technology integration in classrooms, infrastructure is a big problem in secondary schools, and BHS was no different: 'If teachers could use frameworks like HPC it will support them to be game' (Noel, Interview 1).

In the focus group, his students shared a similar connectivity frustration and they perceived that some of their subjects used a lot more technology than others. One student said, 'Some teachers give us educational apps to use and others don't at all - my laptop often stays in my bag all day' (Focus group, Year 7, BHS). They shared an appreciation for their teachers' efforts to set such tasks as a means to boost opportunities for creativity, the following comment being typical:

I find it a lot more interesting when we do this kind of work, it's creative this term we are doing a more open-ended project based on something real something that matters to us - we can expand our ideas - last term we did gender equality in India - I couldn't relate to that. (Focus group, Year 7 BHS).

Vignette 6: Paul

Paul had an inconsistent relationship with technology and only used it when he thought it was going to enhance what students were doing as 'often it became the lesson rather than what was learned' (Paul, Interview 1). He was active in his support of students working in teams and spoke at length about each of the HPC conceptions and themes and how they were present in his teaching. His responses were peppered with enthusiasm for a new pedagogical scaffold. On the other hand he expressed disappointment that much of his lesson preparation time was focused on preparing students for examinations: 
I understood I was preparing them for the real world. I think exams are the quite the waste because at no time in life do you sit down with zero access to notes for 45 minutes or three hours or whatever and only write what you can remember. (Paul, Interview 1)

Paul maintained the PBL task was successful. However, he noted that there were things that could be improved, for example, the student products were good because they created space for the boys, but the ability of the students to present visually what they had learned was weak: 'Weebly was not the best tool to present with and the students did not really take on their roles as designers, architects, and creators' (Paul, Interview $1)$.

In summary, all HPC conceptions were demonstrated in the lessons of Sue, Noel and Paul. Theory manifested in terms of what was constructed through set tasks in the design booklet, the planning and intersection of regular blog posting. From creativity, the project ticked many of the HPC themes - especially in terms of the final plan for a space that had to be pitched to an adult audience. Public learning was satisfied. Life preparation was evident in the school executive and the parent body being able to view outcomes of the design process. Contextual accommodations focused on themes of nurturing community, and teacher commentary that embraced technology integration really defined the game of professionalism.

One overriding word permeated the data collected in vignettes 4 to 6 :'exhausting'. It was used to convey the intensity of PBL in comparison to other teaching methods. However, the 'benefits it offered to learning outweighed reasons not to do it' (Sue, Noel and Paul, Interview 2). 


\section{Vignette 7: Bella}

Bella, the head teacher at MHS, is considered a leading practitioner in the field of technology integration, having presented her work at state, national and international education conferences. Her role in this research was to discuss what the teachers planned to focus on and how they might integrate technology using the HPC conceptions and themes. Professional development with a technology focus was high on her list of priorities as a head teacher, and she co-taught in colleagues' classrooms when invited. Bella supported the teachers to identify the HPC conceptions and themes:

I was able to identify and name the aspects of their teaching practice that they wished to target in relation to the integration of technology in their classrooms. This meant providing them with more effective advice and support.

She explained why pedagogical frameworks like HPC are important for teachers to use when they integrate technology:

As an English teacher I know the value of language, especially metalanguage. I think that frameworks like HPC provide teachers (and those in roles like mine) with the ability to communicate clearly what needs to be achieved with the integration of technology. This saves time and ensures there is a complete understanding of the purpose/intent of ICT specifically in relation to learning. A quality framework perfectly encapsulates the nexus between theory/intent and practice.

Field notes made during the data collection phase recorded Bella's strong support for her teachers via face-to-face interactions, email follow-up and phone calls. 


\section{Discussion}

This case study features seven teacher vignettes from two Australian secondary schools. It has implications for how teachers with support from targeted professional development and assistance from a head teacher might use a pedagogical framework to integrate technology into classroom learning. Limitations of claims rest on understanding that it is a small-scale study and is not generisable (Yin, 2009). However, it does provide examples of naming practices and processes that are critical when integrating technology. Teachers responded positively, and each of the five HPC conceptions and underpinning themes were strongly present in lessons. This might be expected as the teachers' professional development was situated in the school context (Kopcha, 2012) and centred on explicit understanding of one framework, and teachers were supported by a head teacher in their lesson planning and programming.

In response to the study's main research question, the HPC framework supported these secondary school teachers not only to integrate technology into student learning, but also to:

- take risks with their pedagogy, in particular shift to more student-centred classrooms

- see stronger links with the digital worlds of students outside the classroom

- $\quad$ keep experimenting with new technologies for classroom learning

- plan and provide further opportunities for students to work in teams to learn the skills of collaboration and problem solving

- push themselves out of their own 'professional comfort zone'

- seek increased opportunites for students to make and produce artefacts in creative ways on the subject matter they learned. 
Teachers seemed surprised at the level of planning and facilitation that permeated this different pedagogical approach but were eager to maintain their use of HPC as the professional satisfaction it provided was 'immense' (Jacob, Carrie and Paul, Interview 2). Comments like this are reflected elsewhere in the data: 'I like this way of teaching', 'It's very clear' and 'I am getting the hang of it - it seems deeper' (Katrina, Sue and Noel, Interview 2).

In terms of the first sub-question of what HPC conceptions and themes the teachers used, the conception of theory dominated. Teachers viewed technology integration in their discipline content as the means to construct learning for students. It was more useful than their 'previous teacher-centred approaches' because it enabled them to actively support students to reflect on what they had learned. Creativity was strong in the data and teachers understood its central role in adolescent learning (Craft, 2011; Kelly, 2012). Overwhelmingly, public learning was present, and in PBL at BHS it was particularly effective even when the final products were disappointing (Hewes \& Hewes, 2016; Larmer, Mergendoller, \& Boss, 2015). Life prepation was a firm focus, with some teachers expressing concern about the role of school examinations and how this limited their time for effecetive technology integration in classrooms (Evers \& Kneyber, 2016; Lingard et al., 2016). The fifth conception, contextual

accommodations, was about teachers providing opportunities for students in groups to solve problems and challenge each other's thoughts (Reynolds, 2015; Wiliam, 2016).

Recurrent themes in the second sub-question show that learning became more engaging when teachers integrated technology. Some students were critical of 'teachers in other classes' who did not use technology (Author, 2015a; Littlejohn, 2016). The question of distractabality of technology in classrooms was raised. However, from the students' point of view if the subject was engaging and what they were required to do 
using technology was interesting then there were fewer reasons not to be on task.

Students who wanted to improve their information literacy skills identified that the finding of good information from websites was a problem. In summary, they found learning was more engaging when they worked in teams, and they liked a focus on producing worthwhile projects that produced 'real' outcomes.

\section{Conclusion}

This paper has illustrated how the HPC framework supported secondary school teachers at two sites to take pedagogical risks and develop their technology integration practices. The conceptions of theory, creativity, public learning, life preparation and contextual accommodations provided a meta-language that made pedagogical strategies and students' learning processes in technology integration more accessible. If secondary school teachers co-plan lessons or units of work with a head teacher who acts as a type of 'instructional coach' in the school context then more technology integration occurs. According to Netolicky (2016), coaching as professional learning 'can (trans)form teachers' senses of professional identity and not just professional learning, but epiphanic life experiences, which can in turn shape professional selves and practices' (p. 24).

This case study raises questions about learning practices that new pedagogical frameworks like HPC invite. As a scaffold, HPC provides a way forward for how secondary school teachers can teach, and it illustrates ways of learning that adolescent students tend to find engaging and motivating (Author, 2015b;2015c). However, its employment may make it incumbent on secondary schools to appoint at least one technology integration head or lead teacher to act as an instructional coach. In this research the head teacher's central role in the study design became more apparent as the 
research progressed; it was not part of the initial design to investigate the head teacher's responsibility or to directly question teachers about it. This aspect would be well worth exploring in future research.

Additional research is needed to build on this case study to examine how HPC may change and/or transform teaching practice in school classrooms. The reimagination of pedagogy in schools is occurring in pockets (Fullan \& Langworthy, 2014) and there are inspiring examples across the globe of education leaders and secondary school teachers who each day, in highly creative and imaginative ways, align how they teach with the ways young people like to learn (Robinson \& Aronica, 2015). Technology integration supported by new pedagogical frameworks in secondary schools is timely, and HPC offers a way forward for teachers and students.

\section{References}

Author (2013). Other details withheld for blind review

Author (2015a). Other details withheld for blind review

Author (2015b). Other details withheld for blind review

Author (2015c). Other details withheld for blind review

Author (2017). Other details withheld for blind review

Abma, T. A., \& Widdershoven, G. A. M. (2011). Evaluation as a rationally responsible practice. In N. K. Denzin and Y. S. Lincoln (Eds.), The Sage handbook of qualitative research ( $4^{\text {th }}$ ed., pp. 669-684). Thousand Oaks: Sage.

Arthur, E. (2013, May 27). Digital Education Revolution - Did it work? Education Technology Solutions. Retrieved from http://educationtechnologysolutions.com.au/2013/05/27/digital-education-revolution-didit-work 
Belbase, S. (2016). Reflective and reflexive beliefs of two pre-service secondary mathematics teachers. European Journal of Educational \& Social Sciences, 1(1), 34-65. Retrieved from http://www.ejess.eu/vol1_1/EJESS_vol1_1_MANID243.pdf

Boss, S., \& Krauss, J. (2014). Reinventing project-based learning: Your field guide to real world projects in a digital age. Eugene, OR: International Society for Technology in Education.

Craft, A. (2011). Creativity and education futures: Learning in a digital age. Stoke-onTrent, England: Trentham Books.

Danolo Partners, (2013). DER mid-program review: Assessing the progress of the DER and potential future directions. Final report. Melbourne, VIC: Danolo. Retrieved from https://docs.education.gov.au/system/files/doc/other/digital_education_revolution_progra m_review.pdf

Department for Education (DfE). (2010). The importance of teaching: Tthe schools whitepaper 2010. Retrieved from https://www.gov.uk/government/publications/theimportance-of-teaching-the-schools-white-paper-2010

Evers, J., \& Kneyber, R. (Eds). (2016). Flip the sSystem: Changing education from the ground up. Abingdon, Oxon: Routledge.

Fullan, M., \& Langworthy, M. (2014). A rich seam: How new pedagogies find deep learning. London: Pearson.

Graham, C. R. (2011). Theoretical considerations for understanding technological pedagogical content knowledge (TPACK). Computers \& Education, 57, 11531160.

Groff, J., \& Mouza, C. (2008). A framework for addressing challenges to 
classroom technology use. Association for the Advancement of Computing in Education Journal, 16,(1), 21-46.

Groundwater-Smith, S., \& Mockler, N. (2016). From data source to co-researchers? Tracing the shift from 'student voice' to student-teacher partnerships. Education Action Research, 24(2), 159-176.

Harris, J. B. (2008). TPACK in inservice education: Assisting experienced teachers' planned improvisations. In AACTE Committee on Innovation \& Technology (Eds.), Handbook of technological pedagogical content knowledge for educators (pp. 251-271). New York, NY: Routledge.

Harris, J. B., \& Hofer, M. (2014). The construct is in the eye of the beholder: School districts appropriations and reconceptualizations of TPACK. In M. Searson \& M. Ochoa (Eds.), Proceedings for the Society for Information Technology in Teacher Education International 2014. (pp. 2519-2526). Cheasepeake, VA: AACE.

Hewes, B. (2016). High possibility classrooms: Using an Australian framework to enhance learning using technology in Australian high schools. e-Teaching: Management Strategies for the Classroom, 9. Retrieved from http://www.acsp.catholic.edu.au/pdf\%20uploads/6\%20e-Teaching_2016 09.pdf

Hewes, B., \& Hewes, L. (2016). Are humans wild at heart? and other epic English projects for Year 9-10. Victoria: Hawker Bronlow. Retrieved from http://files.hbe.com.au/samplepages/HB7392.pdf

Howard, S., \& Gigliotti, A. (2013). DER-NSW evaluation: Report on the implications of the 2012 data. NSW Education and Communities \& University of Wollongong. Retrieved from https://www.det.nsw.edu.au/media/downloads/about-us/how-weoperate/national-partnerships-program/digital-education-revolutionnsw/rrq1/research/der-data-collection-2012.pdf 
Howard, S., \& Mozejko, (2013). DER-NSW evaluation: Conclusions from 2013 data collection. Wollongong, NSW: University of Wollongong. Retrieved from http://ro.uow.edu.au/cgi/viewcontent.cgi?article=1542\&context=sspapers

Kelly, R. (2012). Educating for creativity: A global conversation. Alberta: Brush Education.

Koh, J., Chai, C., \& Lee, M. (2015). Technological pedagogical content knowledge (TPACK) for pedagogical improvement: Editorial for special issue on TPACK. The Asia-Pacific Education Researcher, 24(3), pp. 459-462. doi: 10.1007/s40299-015-0241-6

Kopcha, T. J. (2012). Teachers' perceptions of the barriers to technology integration and practices with technology under situated professional development. Computers \& Education, 59(4), 1109-1121.

Larmer, J., Mergendoller, J., \& Boss, S. (2015). Setting the standard for project based learning: A proven approach to rigorous classroom instruction. Alexandria, VA: ASCD.

Lin, C. H., Zhang, D., \& Zheng, B. (2017). Preparing foreign language teachers for next generation education. Hershey, PA: IGI Global.

Lingard, B., Thompson, G., \& Sellar, S. (2016). National testing in schools:An Australian assessment. Abingdon: Routledge.

Littlejohn, C. (2016). Messy or not: The role of education institutions in leading successful applications of technology in teaching and learning. Australian Education Leadership, 38(3), 62-65.

Masters, G. (2014). Is school reform working? Policy insights. Melbourne,VIC: Australian Council for Educational Research.

Mazur, E. (2016, August 20). Assessment: The silent killer of learning, Keynote/ 
Plenary talk, iOnTheFuture4, Turramurra North Public School, NSW, Australia, 20 August. Retrieved from Mazur Group website: http://mazur.harvard.edu/search-talks.php?function=recent

Miles, M. B., \& Huberman, A. M. (1994). Qualitative data analysis: An expanded sourcebook. Thousand Oaks: Sage.

Mishra, P., \& Koehler, M. J. (2006). Technological pedagogical content knowledge: A new framework for teacher knowledge. Teachers College Record, 108(6), 10171054.

Moyle, K. (2015). 'Are we they yet?’ Revisiting the Digital Education Revolution. Curriculum Perspectives, 35(2), 64-69.

Netolicky, D. (2016). Down the rabbit hole: Professional identities, professional learning, and change in one Australian school. $\mathrm{PhD}$ thesis, Murdoch University,. NSW Department of Education and Training. (2003). Quality teaching in NSW public schools: A discussion paper. Ryde, Australia: Professional Support and Curriculum Directorate.

Reynolds, R. (2015). Technology for teaching civics and citizenship: Insights from teacher education. The Social Educator. 33(1), 26-38.

Robinson, K., \& Aronica, L. (2015). Creative schools. New York: Viking.

Selwyn, N. (2014). Distrusting educational technology: Changing questions for changing times. New York: Routledge.

The White House: Office of the Press Secretary (2015). FACT SHEET: Obama administration announces more than $\$ 375$ million in public and private support for next-generation high schools. Retrieved from https://www.whitehouse.gov/sites/default/files/docs/fact sheetwhite house summit_on next-generation high_schools.pdf 
Wagner, T., \& Dintersmith, T. (2105). Most likely to succeed: Preparing our kids for

the innovation era. New York: Scribner.

Wiliam, D. (2016). Leadership for teacher learning. West Palm Beach, FL:

Learning Sciences International.

Yin, R. K. (2009). Case study research: Design and methods. Thousand Oaks: SAGE.

Word count of text 6062

Word count of references 938

Total 7000 


1
1
3
4
5
6
7
8
9
10
11
12
13
14
15
16
17
18
19
20
21
22
23
24
25
26
27
28
29
30
31
32
33
34
35
36
37
38
39
40
41
42
43
44
55
50
56
57
48
59
50
51
53
50

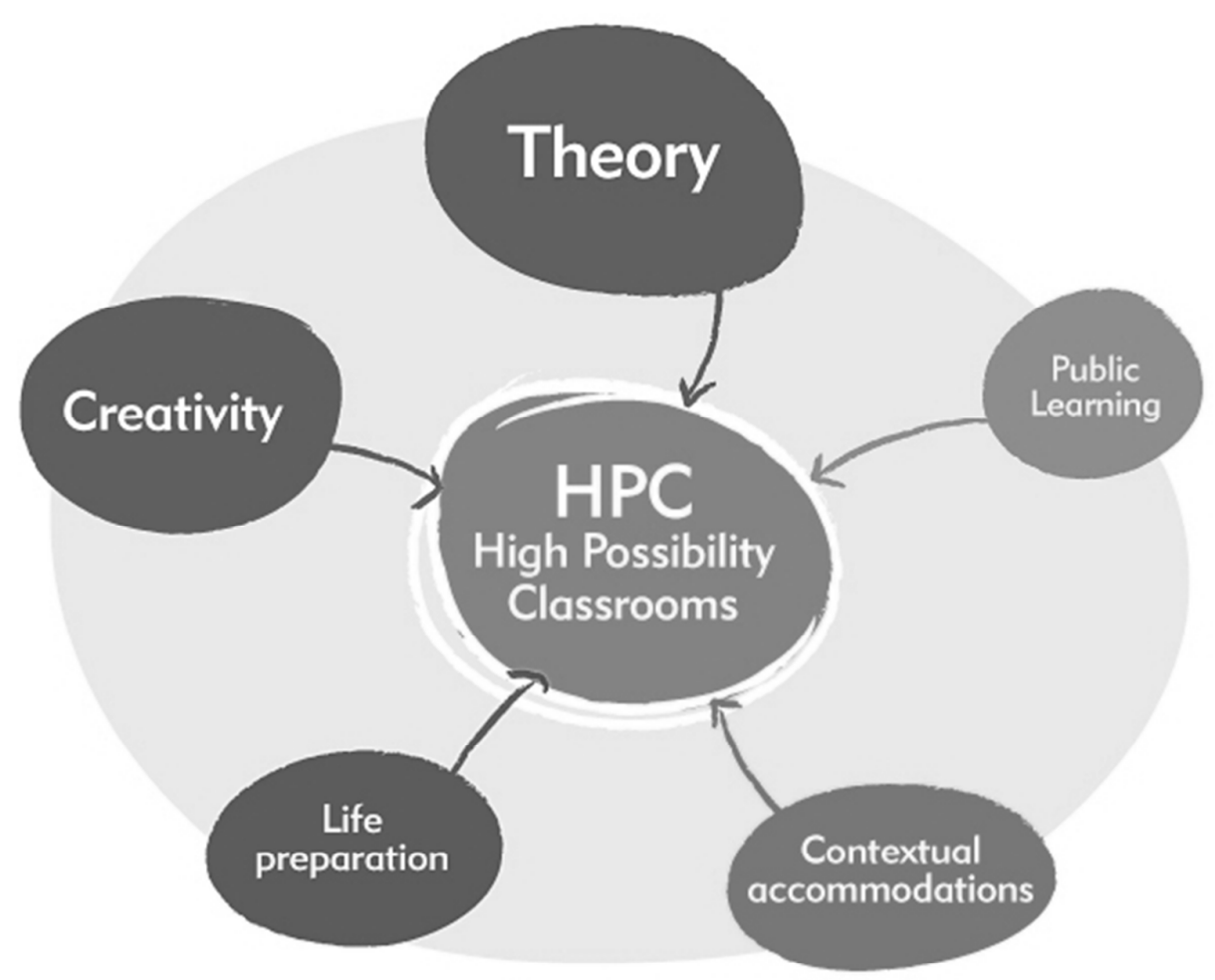

Figure1: Five conceptions of the HPC framework 


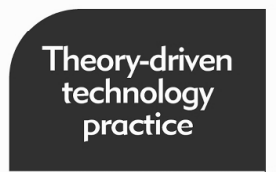

Technology drives construction of learning

Technology enhances purposeful teaching

Technology

focuses planning

Technology enriches subject matter

Technology promotes reflective learning

Technology shifts conversation and thinking

Technology engages students in authentic ways

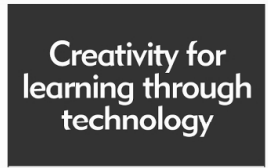

Technology boosts creativity

Technology creates opportunities for production

Technology unleashes playful moments

Technology supports values

Technology differentiates learning

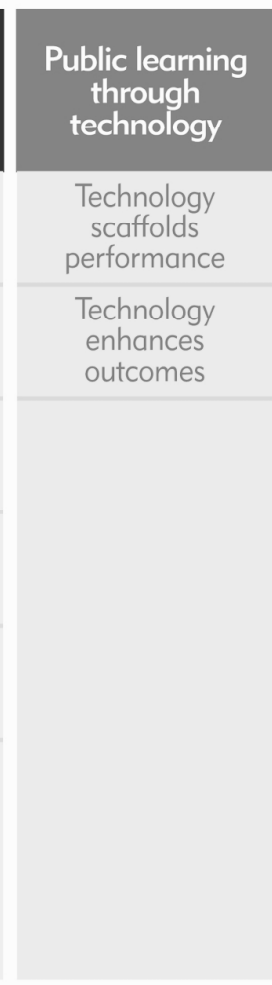

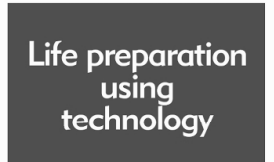

Technology operationalises the real world

Technology gives voice

Technology means ownership
and possibility

Technology reveals effectiveness

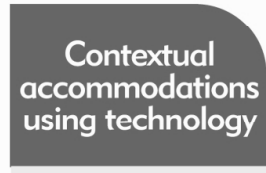

Technology remains personal and professional

Technology changes time

Technology nurtures community

Technology defines the game

Table 1: Twenty-two themes of processes and strategies that underpin the five HPC conceptions 


\begin{tabular}{|l|l|l|l|l|}
\hline Name & School & $\begin{array}{l}\text { Years of } \\
\text { teaching } \\
\text { experience }\end{array}$ & $\begin{array}{l}\text { Curriculum } \\
\text { area }\end{array}$ & $\begin{array}{l}\text { Age group } \\
\text { taught/year/role }\end{array}$ \\
\hline 1.Jacob & MHS & 2 & $\begin{array}{l}\text { Health \& Physical } \\
\text { Education }\end{array}$ & $\begin{array}{l}12-13 \text { y.o. } \\
\text { Year 7 } \\
\text { classroom teacher }\end{array}$ \\
\hline 2.Carrie & MHS & 10 & Science & $\begin{array}{l}14-15 \text { y.o. } \\
\text { Year 8 } \\
\text { classroom teacher }\end{array}$ \\
\hline 3.Katrina & MHS & 5 & English & $\begin{array}{l}15-16 \text { y.o. } \\
\text { Year 10 } \\
\text { classroom teacher }\end{array}$ \\
\hline 4.Sue & BHS & 12 & $\begin{array}{l}12-14 \text { y.o. } \\
\text { Year 7 } \\
\text { classroom teacher }\end{array}$ \\
\hline 5.Noel & BHS & 31 & $\begin{array}{l}12-14 \text { y.o. } \\
\text { Year 7 } \\
\text { classroom teacher } \\
\text { computer } \\
\text { coordinator }\end{array}$ \\
\hline 6.Paul & BHS & 14 & $\begin{array}{l}12-14 \text { y.o. } \\
\text { Year 7 } \\
\text { classroom teacher }\end{array}$ \\
\hline 7.Bella & MHS & 12 & History & $\begin{array}{l}12-18 \text { y.o. } \\
\text { Years7-12 } \\
\text { head teacher }\end{array}$ \\
\hline
\end{tabular}

Table 2: Participant demographic data 